\title{
Endogenous Preferences, Environmental Law
}

\section{Citation}

Cass R. Sunstein, Endogenous Preferences, Environmental Law (Program in Law \& Economics Working Paper No. 14, 1993).

\section{Published Version}

http://chicagounbound.uchicago.edu/law_and_economics/193/

\section{Permanent link}

http://nrs.harvard.edu/urn-3:HUL.InstRepos:12921747

\section{Terms of Use}

This article was downloaded from Harvard University's DASH repository, and is made available under the terms and conditions applicable to Other Posted Material, as set forth at http:// nrs.harvard.edu/urn-3:HUL.InstRepos:dash.current.terms-of-use\#LAA

\section{Share Your Story}

The Harvard community has made this article openly available.

Please share how this access benefits you. Submit a story.

Accessibility 


\section{University of Chicago Law School Chicago Unbound}

Coase-Sandor Working Paper Series in Law and

Economics

Coase-Sandor Institute for Law and Economics

1993

\section{Endogenous Preferences, Environmental Law}

Cass R. Sunstein

Follow this and additional works at: http://chicagounbound.uchicago.edu/law_and_economics Part of the Law Commons

\section{Recommended Citation}

Cass R. Sunstein, "Endogenous Preferences, Environmental Law" (Program in Law and Economics Working Paper No. 14, 1993).

This Working Paper is brought to you for free and open access by the Coase-Sandor Institute for Law and Economics at Chicago Unbound. It has been accepted for inclusion in Coase-Sandor Working Paper Series in Law and Economics by an authorized administrator of Chicago Unbound. For more information, please contact unbound@law.uchicago.edu. 


\section{CHICAGO}

JOHN M. OLIN LAW \& ECONOMICS WORKING PAPER NO. 14 (2D SERIES)

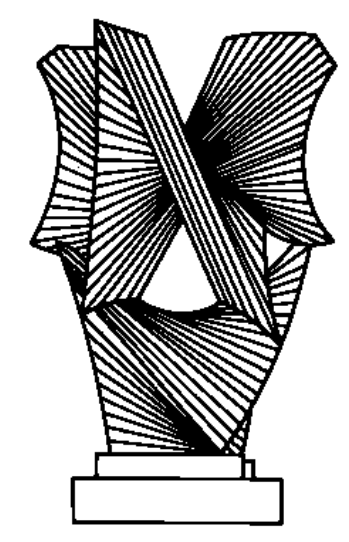

ENDOGENOUS PREFERENCES, ENVIRONMENTAL LAW

Cass R. Sunstein 


\section{Endogenous Preferences, Environmental Law}

\section{Cass R. Sunstein}

How can we explain the rise of environmental law? By what criteria should we evaluate regulation of pollution? Why do some cities require recycling? Should we tax waste disposal instead? Should we subsidize mass transit in order to reduce automobile pollution, or should we regulate cars? Why do we do one rather than another?

In the last generation, considerable progress has been made on all of these questions. Most of the progress results from the application of varieties or offshoots of welfare economics - expected utility theory, social and public choice theory, and game theory-to environmental problems. If we assume, for example, that participants in the political process are trying to maximize their utility, we can help explain many oddities of American environmental law. We can see why some statutes seem to benefit regional interests. ${ }^{1}$ We can understand why old pollution sources are regulated more severely than new ones. ${ }^{2}$ We can see why Congress enacts measures that are expensive and only moderately helpful to the environment, but that promise to deliver large benefits to wellorganized groups. ${ }^{3}$ Perhaps most important, we can understand the omnipresence of largely symbolic environmental legislation-measures that appear on their face to promise vigorous and even draconian regulation, but that in the enforcement process amount to little more than mere words. The pervasive paradox of rigid but underenforced environmental legislation may well match the electoral self-interest of legislators. ${ }^{4}$

* Karl N. Llewellyn Professor of Jurisprudence, University of Chicago, Law School and Department of Political Science. I am grateful for very helpful comments from Douglas Baird, Gary Becker, William Landes, Martha Nussbaum, Randall Picker, and Richard Posner, and from participants in a workshop at the California Institute of Technology. Gabriel Gore provided excellent research assistance. For financial support I am grateful to The Russell Baker Scholars Fund and The James H. Douglas, Jr. Fund for the Study of Law and Government.

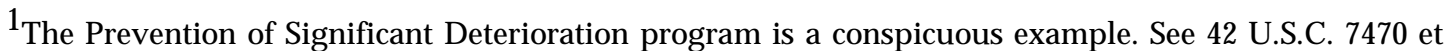
seq. See Peter Pashigian, Environmental Regulation: Whose Self-Interests Are Being Protected?, in Chicago Studies in Political Economy 498 (George Stigler ed. 1988).

${ }^{2}$ This approach is pervasive in environmental law. See, e.g., 42 U.S.C. 7475; 42 U.S.C. 7411; 33 U.S.C. 301.

${ }^{3}$ Examples include the emphasis on "scrubbing" coal, see Bruce Ackerman \& William Hassler, Clean Coal/Dirty Air (1981), and more recently the clean fuels provisions of the 1990 Clean Air Act, see Jonathan Adler, Clean Fuels, Dirty Air, in Michael Greve \& Fred Smith, Environmental Politics 19 (1991).

\footnotetext{
${ }^{4}$ See Cass R. Sunstein, Paradoxes of the Regulatory State, 57 U. Chi. L. Rev. 407 (1990).
} 
With similar tools, we can also think about how best to protect the environment. ${ }^{5}$ Many people do want a cleaner environment-to protect life, health, recreational opportunities, endangered species, and so forth. Many people want other things as well, including lower prices, less poverty, and greater employment. In light of the plurality of goods at stake, it is familiarly suggested that we might try to achieve the optimal level of environmental protection, understanding the notion of optimality by reference to people's real desires. This approach might claim a salutary neutrality among diverse goods and among different conceptions of the good. It takes people and preferences simply as they are.

Approaches of this general sort have provided illuminating work on the genesis of state and federal environmental law. No predictive tool has similar power, and if we want to understand the structure of environmental regulation, much progress remains to be made through use of the same analytic strategies. On the normative side, things are more complex. But at least it seems fair to say that we now lack an alternative framework for normative thinking in the environmental area that can claim to combine the virtues of real-world administrability and substantive plausibility. The extraordinary influence of welfare economics in the regulatory sector of the federal government ${ }^{6}$ is undoubtedly at least in part attributable to this fact.

At the same time, the last decade has witnessed a number of intriguing qualifications, refinements, or criticisms of rational actor models, coming mostly from economists, but also from philosophers, political scientists, and psychologists.7 Some of the work involves "anomalies" of various sorts. The

${ }^{5}$ See, e.g., William Baumol and Wallace Oates, The Theory of Environmental Policy (2d ed. 1988); William Baxter, People Not Penguins (1975); Richard Epstein, Nuisance Law: Corrective Justice and Its Utilitarian Constraints, 8, J. Legal Stud. 49 (1979); Richard Epstein, The Principles of Environmental Protection: The Case of Superfund, 2 Cato Journal 9 (1982).

${ }^{6}$ The influence is clear especially with the Office of Information and Regulatory Affairs (OIRA) in the Office of Management and Budget, the regulatory "czar" that oversees regulatory decisions, including those of the Environmental Protection Agency. OIRA has undertaken cost-benefit analysis, and applied many principles recommended by economists, in the implementation of Exec. Ord. 12291, 3 CFR 127, reprinted in 5 U.S.C. 601 note (1988) and Exec. Ord. 12498, 3 CFR 323, reprinted in 5 U.S.C. 601 note (1988). The status of these executive orders is now under review by the Clinton Administration.

${ }^{7}$ The relevant work is extremely diverse. See, e.g., Richard Thaler, Quasi-Rational Economics (1990); Richard Thaler, The Winner's Curse (1991); Thomas Schelling, Choice and Consequence (1986); George Ainslie, Picoeconomics (1992); Jon Elster, Sour Grapes (1983); Gary Becker and Kevin Murphy, A Theory of Rational Addiction, 94 J. Pol. Econ. 675 (1988); Amartya Sen, Inequality Reexamined (1992); W. Kip Viscusi, Fatal Tradeoffs, chapters 6, 7, and 8 (1992); Jon Elster, Ulysses and the Sirens (1979); Daniel Kahneman and Aaron Tversky, Prospect Theory: An Analysis of Decision under Risk, 47 Econometrica 263 (1979); C.C. von Weiszacker, Notes on Endogenous Change of Tastes, 3 J. Econ. Theory 345 (1971); Gary Becker, The 
institutional implications of these qualifications and refinements are only beginning to receive sustained elaboration. ${ }^{8}$ My principal goal in this essay is to identify some of those implications in the distinctive context of environmental regulation. Some of the apparently normative challenges to rational actor models turn out to have important positive implications. The challenges point to facts about human behavior and motivation that help explain some of American environmental law, and indeed do so in a way that might add much to the descriptive and predictive work of existing approaches. My particular interest is in the endogeneity of preferences and the social "demand" for regulation, which turns out to have peculiar dimensions.

Throughout the paper, I will attempt to show how qualifications of rational actor models generate testable hypotheses, and to explore whether such qualifications offer plausible ways to understand the odd shape of current environmental policies. ${ }^{9}$ In many cases, however, our current tools do not enable us to sort out the role of plausible but competing explanations for regulatory phenomena. An important task for the future, both conceptual and empirical, is to develop better strategies for assessing causal explanations that although strikingly different, would produce similar outcomes. Moreover, some challenges to preference satisfaction as a normative ideal have unusual characteristics in the environmental area. It is worth elaborating on those characteristics.

The paper is organized into four sections. The first suggests that there is sometimes no such thing as a fully acontextual "preference" and that preferences are endogenous to existing legal policy, including the setting of the legal

Economic Way of Looking at Life, University of Chicago, Law \& Economics Working Paper No. 12, pp. 1519 (1993). A helpful collection is Rationality in Action (Paul Moser ed. 1990), especially Part IB.

${ }^{8}$ A leading essay is Roger Noll \& James Krier, Some Implications of Cognitive Psychology for Risk Regulation, 19 J. Legal Stud. 747 (1990). See generally Herbert Hovenkamp, Legal Policy and the Endowment Effect, 20 J. Legal Stud 225 (1991); Elizabeth Hoffman \& Matthew Spitzer, The Divergence Between Willingness-to-Pay and Willingness-to-Accept Measures of Value, Wash. U. L. Q. (forthcoming); Elizabeth Anderson, Some Problems in the Normative Theory of Rational Choice, With Consequences for Empirical Research (Univ. of Mich., Dept. of Philosophy, unpublished manuscript). See also Gary Becker, The Economic Way of Looking at Life, University of Chicago, Law \& Economics Working Paper No. 12, at 19 (1993): "An important step in extending the traditional analysis of individual rational choice is to incorporate into the theory a much richer class of attitudes, preferences, and calculations."

${ }^{9}$ I have discussed some of these issues elsewhere, but with a view to normative rather than positive issues. See Cass R. Sunstein, Preferences and Politics, 20 Phil. \& Pub. AV. 3 (1991); Cass R. Sunstein, The Partial Constitution ch. 6 (1993). In this essay, I stress positive issues, and in a number of places extend or qualify some of my earlier normative claims. Except for a brief section of Part II, I do not discuss the important distorting effect of various "heuristics" used to assess risk. See Noll \& Krier, supra note 8; W. Kip Viscusi, Fatal Tradeoffs ch. 7 (1992). The use of these heuristics also has important positive and normative implications. 
entitlement. This point helps both to explain legislative outcomes and to unsettle some common views about environmental protection on the predictive and normative sides. ${ }^{10}$

The second section claims that private preferences for environmental goods may be adaptive to existing environmental options, and that this can sometimes help explain the social demand for regulation and also "impeach" the preferences that serve as inputs into environmental decisions. The second section also briefly describes the role of the availability heuristic, intrapersonal collective action problems, and the phenomenon of social cascades.

The third section argues that there may be a disparity between private consumption choices and collective judgments, as these are expressed in politics. Partly because of some unusual free-rider problems, preferences may be endogenous to the setting in which they are expressed, and in a way that casts additional doubt on the assumption that preferences can be taken as acontextual.

The fourth and most speculative section argues that people may not always think that there is commensurability between environmental quality and the things against which this good must be "traded off." The social resistance to commensurability helps explain some apparent oddities in the demand for legislation and in public thinking about environmental problems. I also suggest that despite its apparent oddity, the resistance to commensurability is plausible as a normative matter. The assumption that environmental and other goods can be assessed along the same metric does violence to some of our considered judgments about how (not how much) to value pristine areas, species, and other environmental amenities.

\section{The Endowment Effect, Status Quo Bias, and Others}

a. Prefatory note and overview.

At the outset it will be useful to offer a catalogue of how law might deal, or fail to deal, with environmental issues. (1) It may fail to resolve collective action problems, conventionally defined. This is a usual understanding of the state of affairs under the common law. (2) It may actually solve collective action problems, conventionally defined. This is a part of the optimistic, "public interest" account of environmental legislation. (3) It may reflect the political power of well-organized private groups, redistributing wealth in their favor

\footnotetext{
${ }^{10}$ I do not discuss the normative issues associated with the criterion of private willingness to pay, which is often said to be crudely correlated with utility. Despite its crudeness, it might be used because of (a) the difficulty of finding other proxies that are realistically usable by policy makers and (b) the wellknown (though in my view overstated) difficulty of making intrapersonal comparisons of utility. On the latter issue, see Interpersonal Comparisons of Well-Being (Jon Elster and John Roemer eds. 1991).
} 
while failing to improve and perhaps even impairing social welfare. This view is prominent in public choice theory. (4) It may be relatively chaotic and arbitrary, reflecting the order in which issues arise rather than aggregating preferences in an accurate way or embodying any coherent social judgment about the public good. This possibility, discussed in political science and economic writing following Arrow's impossibility theorem, ${ }^{11}$ has been infrequently explored in the regulatory and environmental setting. (5) It may be a product of a process of deliberation among citizens and representatives in which private preferences for environmental amenities are transformed and shaped through exposure to new information and new perspectives.

In practice, it may not be easy to distinguish among some of these different possibilities. For example, (3) and (5) are especially hard to separate; we cannot easily test whether some measure claimed to be (5) is in fact (3). But it is useful to keep these possibilities in mind while thinking about both the positive and normative issues.

In this section, I argue that sometimes there are no acontextual preferences with which to do normative or positive work. Preferences can be a function of the initial allocation of the legal entitlement. valuation of environmental goods is sometimes an artifact of law. When this is so, policy makers cannot simply identify preferences and try to satisfy them, since the preferences are influenced by law, and since there is no way to identify the preferences that would exist in the absence of law.

\section{b. A conceptual problem.}

The initial problem is that it may be impossible to describe something as a "preference" without undertaking some controversial normative tasks. Suppose someone decides not to recycle all newspapers, or to vote against a law requiring recycling. This preference might be understood as simply a choice, as in the idea of the "revealed preference." It is of course illuminating to catalogue and explain choices. But if this is what we are doing, it is unnecessary and perhaps misleading to use the notion of a "preference," which seems to be intended to explain or to back something called choices. If preferences are reducible to choices, we can dispense with the idea entirely. But if we do this, much of the explanatory value of expected utility and rational choice theory will be lost, ${ }^{12}$ since it will be necessary to give up on the notion of an underlying causal

\footnotetext{
${ }^{11}$ See Kenneth Arrow, Social Choice and Individual Values (2d ed. 1963). For a critique, see Richard Pildes \& Elizabeth Anderson, Slinging Arrows at Democracy: Social Choice Theory, Value Pluralism, and Democratic Politics, 90 Colum. L. Rev. 2121 (1990)

${ }^{12}$ See Amartya Sen, Behavior and the Concept of a Preference, 40 Economica 241 (1973).
} 
relationship between choices and internal mental states. An important goal of rational choice theory has been to help show how choices connect with preferences, defined independently of choices. It would be unfortunate to have to dispense with this goal.

On the other hand, the notion of a "preference" is often meant to refer to not to choices themselves, but to something that lies behind and accounts for choices. ${ }^{13}$ But this idea introduces difficulties of its own, difficulties that the "revealed preference" idea was intended to overcome. What is this thing called a "preference"? Is it a steady mental state? A physical entity? How can it be identified or even described? In light of the extraordinary complexity of internal mental states-including whims, second-order preferences, aspirations, judgments, drives of various kinds, and so forth-it is not simple to identity a "preference" as something that stands behind choices and explains them. In the environmental area, the problem is serious. For example, a decision not to recycle is a choice, but the relationship between that choice and an independent entity called a "preference" is often obscure. I will not belabor these complex matters here ${ }^{14}$ and will instead proceed as if it were possible to overcome the relevant difficulties.

c. The Coase theorem and the endowment effect.

With respect to environmental issues, it is natural to begin with the Coase theorem. ${ }^{15}$ Notably, the theorem was originally developed in the context of an environmental problem arising in the law of tort. Coase's conclusion was of course that in the absence of transaction costs, the initial assignment of a legal entitlement will be irrelevant to (a) the ultimate use of property or (b) the level of the relevant activities. The theorem suggests, for example, that where transaction costs are zero, it does not matter whether an entitlement is given to breathers or to polluters, to railroads or to farmers. The two will in any case bargain to a result which is both efficient and (more striking) the same.

It should be plain that the Coase theorem (like most illuminating work in economics) takes preferences as both static and given. This is a key feature of the claim that the ultimate use of property, and ultimate activity levels, are unaffected by the allocation of the entitlement.

\footnotetext{
${ }^{13}$ See George Stigler \& Gary Becker, De Gustibus Non Est Disputandum, 67 Am. Econ. Rev. 76 (1977).

${ }^{14}$ Some of these issues are discussed in Amartya Sen, supra, note 12; Elizabeth Anderson, Some Problems in the Normative Theory of Rational Choice (University of Michigan, Department of Philosophy, unpublished manuscript 1991); Jean Hampton, The Failure of Expected Utility Theory as a Theory of Reason (University of Arizona, Department of Philosophy, unpublished manuscript 1992).

${ }^{15}$ See Ronald Coase, The Problem of Social Cost, 3 J. Law \& Econ. 1 (1960).
} 
But insofar as the theorem says that the result will be the same independently of the legal rule, it rests on an intriguingly false assumption, one that suggest that it may sometimes be impossible for government to take preferences "as they are." The problem is that whether people have a preference for a good, a right, or anything else is often in part a function of whether the government, or the law, has allocated it to them in the first instance. There is simply no way to avoid the task of initially allocating a legal entitlement, ${ }^{16}$ at least short of anarchy (the only system without initial allocations). What people "have" is partly a product of what the law protects. And with respect to environmental amenities, what people have is, simply as a matter of fact, a creation of legally-conferred rights. ${ }^{17}$

The key point is that the decision to grant an entitlement to A rather than $\mathrm{B}$ can affect the valuations of that entitlement by both A and B. More specifically, the initial grant of the entitlement to $A$ frequently makes $A$ value that entitlement more than he would if the right had been allocated to B. (It also makes B value it less than he otherwise would..$^{18}$ ) The initial allocation-the legal rule saying who owns what, before people begin to contract with one another-serves to create, to legitimate, and to reinforce social understandings about presumptive rights of ownership. That allocation can help produce individual perceptions about the entitlement in question. ${ }^{19}$ It should be clear that if this is so, the demand for environmental regulation will be importantly affected by the initial allocation.

\footnotetext{
16“"When a loss is left where it falls in an auto accident, it is not because God so ordained it. Rather it is because the state has granted the injurer an entitlement to be free of liability and will intervene to prevent the victim's friends, if they are stronger, from taking compensation from the injurer.... [A]n entitlement to a good or to its converse is essentially inevitable. We either are entitled to have silence or entitled to make noise in a given set of circumstances. We either have the right to our own property or body or the right to share others' property or bodies. We may buy or sell ourselves into the opposite position, but we must start somewhere." Guido Calabresi \& A. Douglas Melamed, Property Rules, Liability Rules, and Inalienability: One View of the Cathedral, 85 Harv. L. Rev. 1089, 1091, 1100-1101 (1972).

${ }^{17}$ I am not speaking here of wealth effects, to which Coase does refer. See Ronald Coase, The Firm, the Market, and the Law 170-74 (1988). Wealth effects consist of the consequences for social demand of shifts in wealth brought about by the allocation of the entitlement. In most real-world cases, it has been persuasively argued that wealth effects are likely to be small. See R.D. Willig, Consumer's Surplus Without Apology, 66 Am. Econ. Rev. 589 (1976), though the point is controversial, see note 36 infra. The empirical work on endowment effects has shown consequences for willingness to pay that do not depend on material changes in wealth. See citations in notes $20 \& 26$ infra. There is thus an important difference between wealth effects and endowment effects. They are not equivalent phenomena.

${ }^{18}$ The popular notion that "the grass is always greener" suggests that preferences may be strongest for things to which people do not have entitlements; but there is apparently no empirical support for this intuitively plausible view.

${ }^{19}$ I do not claim that private preferences are always an artifact of law. In some cases, people order their affairs on the basis of social norms that operate independently of law, and the preferences that undergird those norms are not legally constructed. See Robert Ellickson, Order Without Law (1991).
} 
The effect on preferences of the initial allocation of a commodity or an entitlement is commonly described as the "endowment effect." ${ }^{20}$ The endowment effect suggests that any initial allocation of an entitlement-and government cannot refuse to make an initial allocation-may well have effects on preferences.

1. Survey evidence and experimental results. This point has received considerable empirical confirmation, often in the context of environmental amenities. Studies based on survey research have found endowment effects in many settings. One such study found that people would demand about five times as much to allow destruction of trees in a park as they would pay to prevent the destruction of those same trees. ${ }^{21}$ When hunters were questioned about the potential destruction of a duck habitat, they said that they would be willing to pay an average of $\$ 247$ to prevent the loss_-but would demand no less than $\$ 1044$ to accept it. ${ }^{22}$ In another study, participants required payments to accept degradation of visibility ranging from 5 to more than 16 times higher than their valuations based on how much they were willing to pay to prevent the same degradation ${ }^{23}$ According to yet another study, the compensation demanded for accepting a new risk of immediate death of $.001 \%$ was one or two orders of magnitude higher than the amount of willingness to pay to eliminate an existing risk of the same magnitude.

A related survey showed similarly large status quo biases in willingness to pay for changes in risks. Thus only 39\% of respondents would accept $\$ 700$ to have their chance of a serious accident increased by $0.5 \%$ (from $0.5 \%$ to $1.0 \%$ ); the substantial majority of $61 \%$ would refuse the trade. By contrast, only $27 \%$ would trade an identical decrease in accident risk (from $1 \%$ to $0.5 \%$ ) for $\$ 700$; here an even larger majority of $73 \%$ would refuse to do. In another study, people were willing to pay $\$ 3.78$ on average to decrease the risk from an insecticide, but $77 \%$ refused to buy the product at any price, however reduced, if the risk level would

\footnotetext{
${ }^{20}$ It was first so-called in Richard Thaler, Toward a Positive Theory of Consumer Choice, 1 J. Econ. Behavior and Org. 39 (1980). This essay, along with others of similar interest, can be found in Richard Thaler, Quasi-Rational Economics (1990).

${ }^{21}$ Dan Brookshire and Don Coursey, Measuring the Value of a Public Good: An Empirical Comparison of Elictation Procedures, 77 Am. Ec. Rev. 554 (1987).

22 Judd Hammock and G. M. Brown, Waterfowl and Wetlands: Toward Bioeconomic Analysis (1974); Robert Rowe et al.,, An Experiment on the Economic Value of Visibility, 7 J. Env. Ec. and Management 1 (1980).

${ }^{23}$ Richard Thaler, Toward a Positive Theory of Consumer Choice, 1 J. Econ. Behavior and Org. 39 (1980). A good overview is Elizabeth Hoffman and Matthew L. Spitzer, The Divergence Between Willingness-to-Pay and Willingness-to-Accept Measures of Value, Wash. U. L. Q. (forthcoming 1993).
} 
increase by an equivalent amount. ${ }^{24}$ In short: A powerful status quo bias affects reactions to environmental risks or losses. ${ }^{25}$

There are of course notorious problems with survey evidence, which is hardly a reliable guide to real-world behavior. But experimental studies reveal similar effects. For example, a recent study showed that people who were given certain objects-pens, coffee mugs, and binoculars-placed a much higher valuation on those objects than did those who were required to purchase them. People initially given such things required a relatively high price from would-be purchasers; people not initially given such things would over a relatively low price to wouldbe sellers. ${ }^{26}$ No such effects were observed for money tokens in otherwise identical experiments.

A similar study gave some participants a mug and others a chocolate bar, and told members of both groups they could exchange one for the other. Participants in a third group, not given either, were told that they could select one or the other; $56 \%$ of these selected the candy bar. By contrast, $89 \%$ of those initially given the mug refused to trade it for the candy bar, and only $10 \%$ of those initially given the candy were willing to trade it for the mug. ${ }^{27}$ The different evaluations apparently could not be explained by reference to anything other than the initial endowment.

Another experiment found a significant disparity between willingness to accept (WTA) and willingness to pay (WTP) in the especially interesting context of irreversible choices about preserving species and other environmental amenities. In one experiment, the authors tried to ascertain the "existence value" of a houseplant that grows like a pine tree. The subjects were told that any trees not sold or kept would be killed at the end of the experiment. The mean willingness to pay to avoid the "kill" option was $\$ 7.81$. The mean willingness to accept payment to allow a tree to be killed was $\$ 18.43 .{ }^{28}$

\footnotetext{
${ }^{24}$ W. Kip Viscusi, Wesley Magat, and Peter Huber, An Investigation of the Rationality of Consumer Valuations of Multiple Health Risks, 18 RAND Journal of Economics 465 (1987).

${ }^{25}$ See generally William Samuelson and Richard Zeckhauser, Status Quo Bias in Decision Making, 1 Journal of Risk and Uncertainty 7 (1988).

${ }^{26}$ Daniel Kahneman, Jack Knetsch, and Richard Thaler, Experimental Tests of the Endowment Effect and the Coase Theorem, 98 J. Pol. Econ. 1325 (1990). See also Jack Knetch, The Endowment Effect and Evidence of Nonreversible Indifference Curves, 79 Am. Econ. Rev. 1277 (1989); Jack Knetch and Sinden, Willingness to Pay and Compensation Demanded: Experimental Evidence of an Unexpected Disparity in Measures of Value, Q. J. Econ. 507 (1984).

${ }^{27}$ Knetch, supra note 26.

${ }^{28}$ See Rebecca Boyce et al., An Experimental Examination of Intrinsic Values as a Source of the WTAWTP Disparity, 82 Am. Econ. Rev. 1366 (1992).
} 
In some studies, the disparity between WTA and WTP-the extent of the endowment effect-appears to diminish with repeated participation in a market. But it rarely disappears entirely, and many studies show that the disparity persists. ${ }^{29}$ The range of the disparity appears to vary from slight disparities to a ratio of more than four to one, with WTA usually doubling WTP. In field studies, environmental goods tend to reflect a disparity of factors from two to over ten. ${ }^{30}$ In some environmental experiments involving trees, the WTAWTP ratio is extraordinarily high, ranging between $60 / 1$ and $90 / 1 .^{31}$

2. Explanations. In many settings, then, it has been shown that people place a higher value on rights or goods that they currently hold than they place on the same goods when in the hands of others. The disparity is puzzling; but there are many possible explanations.

Some studies suggest that that assignment creates the basic "reference state" from which judgments of fairness are subsequently made, and those judgments affect preferences and private willingness to pay. ${ }^{32}$ On this account, people perceive things as fair if they stay close to the status quo, and judgments of fairness connect to preferences. An especially influential approach to the endowment effect stresses "loss aversion," which refers to the fact that a negative change from the status quo is usually seen as more harmful than a positive change is seen as beneficial. Here too there is a status quo bias. ${ }^{33}$

Perhaps, too, people prefer what they have to what they might have because of psychological attachments to existing allocations. Endowment effects may thus reflect an effort to reduce cognitive dissonance. High valuation of what one owns, and low valuation or what one does not, is a means of reducing dissonance, and in some respects it is highly adaptive. It may well be welfarepromoting. ${ }^{34}$ Perhaps the initial allocation has an important legitimating effect. ${ }^{35}$

${ }^{29}$ See the overview in Hoffman \& Spitzer, supra note 39.

${ }^{30}$ See Boyce et al., supra note 28, at 1366 .

${ }^{31}$ David S. Brookshire and Don L. Coursey, Measuring the Value of a Public Good: An Empirical Comparison of Elicitation Procedures, 77 Am. Econ. Rev. 554 (1987).

${ }^{32}$ See Daniel Kahneman, Jack Knetsch, and Richard Thaler, Fairness and the Assumptions of Economics, in Rational Choice: The Contrast Between Economics and Psychology 101, 113-14 (1987). See also Edward Zajac, Perceived Economic Justice: The Example of Public Utility Regulation, in Cost Allocation: Methods, Principles, Applications (H. Peyton Young ed. 1985).

${ }^{33}$ See, e.g., Roger Noll \& James Krier, Some Implications of Cognitive Psychology for Risk Regulation, 19 J. Legal Stud. 747 (1990). This argument was originally offered in Richard Thaler, Toward a Positive Theory of Consumer Choice, 1 Journal of Economic Behavior and Organization 39 (1980).

${ }^{34}$ See Shelley Taylor, Positive Illusions (1989).

${ }^{35}$ See Edward Zajac, supra, note 92. 
It may suggest that the entitlement "naturally" belongs where it has been placed, and therefore put a social burden on even voluntary changes. In some cases the divergence between willingness to pay and willingness to accept is probably a product of the change in social attitudes brought about by the change in the allocation of the entitlement. With respect to sexual harassment, for example, the mere shift in the entitlement appears to have had significant attitudinal effects. The example may be generalizable.

There are other possibilities. Endowment effects may come from experience; people who use a product or have an entitlement may learn to appreciate its value. They may be a product of strategic considerations. Someone may be unwilling to give up a right because the concession would reveal weakness in bargaining. Sometimes apparent endowment effects might be produced by the wealth effect of the initial allocation of the entitlement. Different allocations produce differences in wealth-someone with more entitlements is to that extent richer-and perhaps some allocations have wealth effects sufficiently large to affect the point to which people will bargain. ${ }^{36}$

Alternately, such effects might derive from what we might call "anticipated ex post regret." ${ }^{\prime 37}$ People who trade one good for another may fear that in the event of disappointment, they will be left not only with a good of uncertain value, but also with a feeling of personal responsibility and thus intense regret for having brought about that very fact. In the environmental context, the explanation may be connected with the fact that substitutes do not exist for some public goods..$^{38}$ Recently it has been suggested that the disparity is connected with intrinsic moral values involving the assignment of moral responsibility for the destruction of environmental assets. The WTA measure assigns responsibility to the individual. The WTP measure does so more ambiguously. ${ }^{39}$ Perhaps some of the disparity can be attributed to the desire to avoid or to minimize the feeling

\footnotetext{
${ }^{36}$ An interesting argument to this effect appears in Michael Hanemann, Willingness to Pay and Willingness to Accept: How Much Can They Differ?, 81 Am. Econ. Rev. 635 ((1991).

${ }^{37}$ Cf. Graham Loomes and Robert Sugden, Regret Theory: An Alternative Theory of Rational Choice Under Uncertainty, 92 Economic Journal 805 (1982); Graham Loomes and Robert Sugden, Disappointment and Dynamic Consistency in Choice Under Uncertainty, 53 Rev. of Economic Studies 271 (1986); David Harless, Actions Versus Prospects: The Effect of Problem Representation on Regret, 82 Am. Econ. Rev. 634 (1992); Chris Starmer and Robert Sugden, Probability and Juxtaposition Effects: An Experimental Investigation of the Common Ratio Effect, 2 J. Risk and Uncertainty 159 (1989); Graham Loomes, Further Evidence of the Impact of Regret and Disappointment in Choice Under Uncertainty, 55 Economica 47 (1988).

${ }^{38}$ See Michael Hanemann, Willingness to Pay and Willingness to Accept: How Much Can They Differ?, 81 Am. Econ. Rev. 635 ((1991).

${ }^{39}$ This is an apparently pervasive social judgment about responsibility, but it must of course be defended; it is not self-evident.
} 
that one has been morally culpable for producing the loss of an environmental amenity. ${ }^{40}$

Notably, some of these explanations do not depend on real preference change at all. They account for endowment effects while holding preferences constant. But these sorts of explanations do not appear sufficient.

For present purposes, it is enough to say that the initial allocation often shapes preferences, and that no legal system can operate without an initial allocation. When this is so, there is no acontextual "preference" with which to do legal or political work. A government deciding on environmental issues cannot be neutral among preferences when-and this is the key point-it does not know what preferences are until it has acted, and when there is no sense in which it can refuse to act (again, short of anarchy).

It is tempting to respond that government might indeed refuse to act-as, for example, by failing to create liability at all. A railroad might be freely permitted to emit air pollution, for example. Is this not a case of inaction? Might not a system of this sort turn out to be neutral, in the sense that it simply allows people to do what they want in light of their (pre-legal) preferences?

The answer is that such a system would not be neutral, that it would not involve inaction, and that it would not simply allow people to do what they want. A decision to permit railroads to emit pollution is a grant, by law, of a legal entitlement. It allocates the relevant right to the railroads. It is not helpful to point to what would happen in anarchy, or in the state of nature. In anarchy or nature, the state does not enforce entitlements at all. In anarchy or nature, the state does not prohibit people from taking corrective action (of whatever sort) when they perceive themselves to be injured. In any legal system, however, a right to pollute is indeed backed by the force of law. It is accompanied by stateenforced prohibitions on certain sorts of corrective action by victims, including physical violence, or the attempted taking, by victims, of relevant property interests. It is in this sense that the state, so long as it exists, inevitably allocates entitlements.

Now let us return to the Coase theorem. In light of the endowment effect, the theorem appears at least sometimes to be inaccurate insofar as it predicts that the allocation of the entitlement will not affect ultimate outcomes. (The theorem remains true insofar as it shows that the result will be efficient regardless of the initial allocation. There is no problem with the theorem to the extent that it says that under ideal conditions, private and social costs are equal.) The difficulty for

\footnotetext{
${ }^{40}$ See Rebecca Boyce et al., An Experimental Examination of Intrinsic Values as a Source of the WTAWTP Disparity, 82 Am. Econ. Rev. 1366 (1992).
} 
this prediction is that it overlooks the effects of the initial allocation on preferences. The endowment effect means that contrary to the Coase theorem, the entitlement will tend to stay where it has been initially allocated. People to whom the entitlement has been initially allocated will value it most, and precisely because of the initial allocation. For example, a grant of the initial entitlement to breathers will probably make them value clean air more than they otherwise would.

\section{d. Status Quo Bias.}

The endowment effect can be understood as a special instance of a much more general phenomenon: status quo bias. In many settings, people appear to give more weight to the status quo than would be predicted by conventional models of rational choice. The phenomenon appears to occur in many places.

Samuelson and Zeckhauser have shown that the affinity for the status quo appears to affect such diverse forms of behavior as brand allegiance, choice of insurance plans, changing public policies, marketing techniques, and investment decisions. ${ }^{41}$ This affinity may be fully rational. It may well reflect the high costs of any transition. It may be that the goods people own become integrated into daily life, so that a form of relocation cost is incurred whenever currently owned goods are lost. Or status quo bias may reflect search costs. Whether or not rational, the phenomenon of status quo bias probably has some of the same roots as the narrower phenomenon of endowment effects. Loss aversion is plausibly at work here; so too with the effort to reduce cognition dissonance, the desire to avoid anticipated ex post regret, and the concern about one's moral responsibility for introducing changes in the status quo. In any case, there is evidence that people are more strongly biased toward the status quo than would be predicted by usual theory about decision-making under uncertainty.

e. Positive implications.

If all this is correct, large consequences follow. We can predict that much governmental behavior in the environmental context will be a product of endowment effects. Private and public reactions to risks should reflect a status quo bias. Both supply and demand will be affected. Government regulation of new risks will predictably be more stringent than government regulation of (equivalent) old risks. This is so precisely because the public demand for regulation will be a product of status quo bias.

\footnotetext{
${ }^{41}$ William Samuelson and Richard Zeckhauser, Status Quo Bias in Decision Making, 1 Journal of Risk and Uncertainty 7 (1988)
} 
This is in fact what we observe. It is a defining characteristic of the current system of environmental controls. ${ }^{42} \mathrm{New}$ risks are regulated far more stringently than old ones, even though this strategy sometimes creates extremely perverse results, by perpetuating the life of the especially severe old risks and thus damaging public health and safety. New stationary sources of air pollution must meet technological requirements not imposed on old sources; new cars are regulated far more heavily than old ones. ${ }^{43}$

The disparity is sometimes explained on the ground that old industries seek to use regulation to stop new entry. ${ }^{44}$ This is a plausible explanation. But without more evidence, we cannot be sure that it is true. The disparity may well result in part from status quo bias. It would be useful to attempt to test the competing hypotheses, perhaps by seeing whether more stringent controls on new sources result when the producers of old sources are better organized.

More generally, political participants should be able to exploit endowment effects by attempting to describe the regulatory status quo in a way that takes advantage of the phenomenon of loss aversion. Politicians are frequently successful when they are able to identify and control the perception of the status quo. One example is provided by constant political efforts to lower expectations by describing the status quo as systemically worse than in fact it is, so that the citizenry will rarely perceive deviations as losses but instead only as gains.

There are many examples in the area of environmental regulation. Consider, for example, the controversial and probably irrational Prevention of Significant Deterioration (PSD) program..$^{45}$ The PSD program says roughly that states that met national ambient air quality standards in 1977 cannot suffer a deterioration in air quality, even if the air would remain very clean, and even if there are good reasons for allowing new development. The use of the 1977 benchmark seems puzzling and even senseless. There is no clear reason to conclude that the air cannot become dirtier than it happened to be in 1977, so long as it is consistent with the other national benchmark standards in the Clean Air Act.

How, then, can we explain the existence of the PSD program, which seems hard to justify on public interest grounds? Certainly part of the explanation comes from public choice theory. Representatives in "clear air" states disproportionately opposed the program, and those in "dirty air" states disproportionately supported it, no doubt in order to prevent the exodus of

\footnotetext{
${ }^{42}$ See Peter Huber, The Old New Division in Risk Regulation, 64 Va. L. Rev. 613 (1984).

${ }^{43}$ See Cass R. Sunstein, After the Rights Revolution (1990).

${ }^{44}$ See Chicago Studies in Political Economy (G. Stigler ed. 1987).

${ }^{45} 42$ U.S.C. 7470 et seq.
} 
revenue-producing, polluting companies to "clean air" states. ${ }^{46}$ But the apparently broad appeal of the PSD program may owe a good deal as well to the endowment effect. The perception that air quality ought at least to stay where it is-that the government should prevent deterioration from the status quoseems to have widespread appeal. This is so despite the fact that other things being equal, regulatory efforts to make the air cleaner than it now is often face strong political roadblocks. The asymmetry cannot be fully explained on public interest grounds, for prevention of deterioration can be far worse than actual improvements. It probably has a good deal to do with status quo bias and with the initial endowment reflected in air quality at the time the legislation was under consideration.

Or consider one of the most-criticized features of the Clean Air and Clean Water Acts, the persuasive requirement that companies adopt the "best available technology" (BAT). ${ }^{47}$ This strategy has been challenged on the ground that there is at best an incidental relationship between cost-effective environmental policy and adoption of BAT. ${ }^{48}$ In principle, it seems unreasonable to require everyone to adopt the best available technology. Instead government should allow companies a high degree of flexibility in achieving air quality goals. Some companies should switch to clean energy sources, rather than put expensive technology on dirty energy sources; some companies should go out of business because once they pay the environmental costs, their activity is not worthwhile; some companies should not use BAT at all, since they do business in regions in which adoption of expensive technology is not sensible in light of the variables at stake.

An interest-group explanation is not entirely implausible for BAT requirements. ${ }^{49}$ But perhaps the requirements can also be understood as an outgrowth of the status quo bias. If the technological status quo is thought to be an appropriate benchmark for legal requirements, its use in environmental law may not be so puzzling. There may be general agreement that the technological

\footnotetext{
${ }^{46}$ Pashigian, supra note 1.

4742 U.S.C. 7475; 42 U.S.C. 7411; 33 U.S.C. 301.

${ }^{48}$ The best discussion is Bruce Ackerman \& Richard Stewart, Reforming Environmental Law, 13 Colum. J. Env. Law 171 (1988).

${ }^{49}$ There are two possibilities here. (a) Industries may Wnd BAT the best of their various options. Predictably, there will be a great deal of pre-enforcement administrative and litigative activity before adoption of BAT; hence the BAT approach will produce comparatively less regulation than (for example) a fee imposed on polluting activity. (b) BAT may be linked with the electoral self-interest of legislators. When statutes requiring BAT are enacted, legislators can claim credit before their constituents, and blame the relevant agencies for the (predictably) low level of enforcement activity.
} 
status quo is the best and fairest foundation for environmental law, even if this view will not survive critical scrutiny..$^{50}$

It is notable too that it appears very difficult (though not impossible) to bring about even rational environmental regulation through tax increases-on, for example, polluting vehicles or gasoline. "Green taxes" are supported by strong justifications; but they are an almost invisible part of national environmental policy. ${ }^{51}$ Perhaps the difficulty can be attributed to the influence of the automobile industry; but some of the spokesmen for the industry have actually favored gasoline taxes. The difficulty may well be understood in terms of the endowment effect, as that effect operates to define the public demand for regulation. The existing price of gasoline marks the status quo from which departures are measured. Government efforts to raise the price therefore meet strong resistance. Hence the public is generally quite hostile to any effort to increase the price of gasoline..$^{52}$

By contrast, there are many popular regulatory requirements that ultimately raise the cost of energy and automobiles, but that do so mostly by affecting new sources. By almost any measure of social welfare, the direct tax approach would be preferable to the regulatory approach..$^{53}$ I do not deny that there are many possible explanations for currently dysfunctional environmental policy. But a contributing factor may be that a tax or fee imposes highly visible losses as compared with the status quo, whereas the regulatory approach does no such thing.

Or consider the fact that subsidies to mass transit might well be an especially sensible and inexpensive environmental strategy. If automobiles are a major contributor to air pollution, an important goal is to reduce vehicle miles traveled, as well as (or instead of) improving pollution control devices on cars. This much seems clear from the fact that regulatory requirements have not succeeded in

\footnotetext{
${ }^{50}$ See the discussion of fairness in Daniel Kahneman, Jack Knetch, and Richard Thaler, Fairness and the Assumptions of Economics, supra note 32.

${ }^{51}$ There is a partial exception in the most recent amendments to the Clean Air Act. The new provisions governing acid deposition create a process by which polluters may purchase the right to emit sulfur dioxide in excess of allowed levels. The purchase will occur both through direct sales and through an innovative auction system. See 42 U.S.C. 7651o. For a good general discussion of green taxes, see W. Kip Viscusi, Wesley Magat, Alan Carlkin, and Mark Dreyfus, Environmentally Responsible Energy Pricing (Duke University, Department of Economics. unpublished manuscript, 1993). Of course President Clinton's proposed energy taxes, defended in part on environmental grounds, may make "green taxes" an important part of national policy.

${ }^{52} \mathrm{Cf}$. the discussion of price increases in Thaler, supra note 20.

${ }^{53}$ See Roger Crandall, Policy Watch: Corporate Average Fuel Economy Standards, 6 J. of Econ. Persp. 171 (1992).
} 
reducing aggregate automobile pollution levels, because the decrease in air pollution per mile traveled has been more than offset by increases in total car use. ${ }^{54}$ It follows that an imperative for environmental policy is to create incentives that will decrease the use of the underlying polluting activity. But this idea has played little role in policy, especially in the area in which it makes most sense: government expenditures devoted to mass transit and highways.

Here too the political influence of the automobile industry is a plausible contributing factor. But status quo bias may play a large role as well. Because Americans have adapted their behavior to frequent use of the automobile, it is especially difficult to change their behavior in the direction of mass transit. This explanation helps to account for the remarkable comparative popularity in Europe of environmental strategies that do deter automobile use and promote mass transit. ${ }^{55}$ In Europe, people have not so deeply adapted their practices and preferences to automobile use.

The point is very general. Public policy often takes the status quo-including, very prominently, the existence of particular firms-as if it were a given. Laws that endanger current institutions are subject to special social scrutiny. To some extent this is fully rational in light of the real costs of transition. But I hypothesize that a large part of the phenomenon is attributable to a bias in favor of the status quo that is far stronger than traditional theory would predict.

f. Normative implications.

Thus far we have seen that many puzzles in current environmental policy might be an outgrowth of the endowment effect and status quo bias. What about on the normative side?

The most general point is that the preference-shaping effects of legal rules cast doubt on the idea that environmental regulation should attempt to satisfy or follow some aggregation of private preferences. If legal rules have inevitable effects on preferences, it is hard to see how a government might even attempt to take preferences "as given" in any global sense. ${ }^{56}$ When preferences are a function of legal rules, the rules cannot be justified by reference to the preferences. ${ }^{57}$ Social rules and practices cannot be justified by practices that they

${ }^{54}$ Roger Crandall, Regulating the Automobile (1986).

${ }^{55}$ See Marcia Lowe, Shaping Cities, in State of the World 1992, at 119 (Lester Brown ed. 1992).

${ }^{56} \mathrm{~A}$ qualification is necessary here. The words "in any global sense" are crucial. Usually the incremental work of law and economics makes perfect sense, because the particular issue does not affect preferences. "Local" neutrality among preferences is therefore fully possible.

${ }^{57}$ See Jon Elster, Sour Grapes (1983). 
have produced. Sometimes there is no such thing as a prelegal or prepolitical "preference" that can be used as the basis for decision.

The point has normative implications for environmental policy. One would expect that a decision to farmers a right to be free from water pollution will have an impact on social attitudes toward clean water. The allocation will affect the valuation of the rights by both current owners and would-be purchasers. In this sense-again speaking globally-neutrality as among preferences cannot be achieved through legal rules, because the preferences will sometimes be a function, or a creation, of legal rules. In setting policy, it may therefore be important to make some choice about the sorts of preferences that ought to be encouraged, rather than to act as if preferences can be kept constant. ${ }^{58}$

None of this suggests that it is generally impossible for those interested in environmental law to work from existing preferences. Sometimes the endowment effect is small, and in any case we can generate a relatively narrow range of prices from which to make policy choices. But in valuation of natural resources, the endowment effect can create a significant problem, one that is impairing efforts to make contingent valuation of resources not traded on markets. ${ }^{59}$ It follows that some ground should ultimately be identified for choosing between the different outcomes that would be produced by preferenceshaping legal rules.

\section{Adaptive Preferences, Intrapersonal Collective Action Problems, Cascades, and} Heuristics

Private preferences are endogenous to current practices, current opportunities, and past consumption. This conclusion follows from the endowment effect. In this section, I generalize the point.

\section{a. Adaptive Preferences.}

People may well adapt their conduct and even their desires to what has been available. Consider here the story of the fox and the sour grapes. The fox does not want the grapes because he considers them to be sour; but his belief to this effect is based on the fact that the grapes are unavailable. It is therefore hard to

\footnotetext{
${ }^{58}$ It is highly notable in this regard that the institutions of the market and democracy-now often defended as neutral among preferences-were originally justified as producing good preferences. On democracy, see J.S. Mill, Considerations on Representative Government (1991; originally published 1861); on the market, see especially the discussion of "doux commerce" in Albert Hirschmann, The Passions and the Interests (1983).

${ }^{59}$ See, e.g., R.G. Cummings, D.S. Brookshire, and W.D. Schulze, Valuing Environmental Goods; An Assessment of the Contingent Valuation Method(1986); Paul Carlin and Robert Sandy, Estimating the Implicit Value of a Young Child's Life, 58 Southern Economic Journal 186 (1989).
} 
justify their unavailability by reference to his preferences..$^{60}$ In the environmental context, it might be hypothesized that the preference for environmental quality will be especially weak among people who have not been exposed to pristine areas, clean water, and clean air. If the point is right, it will have important implications for positive and normative work. ${ }^{61}$

To be sure, it will be hard to test this hypothesis in any authoritative way. There is an overlap between a lack of information on the one hand and an adaptation of preferences to what is available on the other. People unexposed to beautiful areas may be uninterested in them not because of an adaptation, but because they lack relevant information. Moreover, people whose preferences are said to have adapted to the absence of environmental quality are likely to be deprived in a general way. If so, it may be best to say not that their preferences have adapted, but that they are choosing rationally and as best they can among a limited set of opportunities. Both of these phenomena-lack of environmental information and apparent devaluation of environmental quality under conditions of deprivation, because of the need to trade it off against other goods-undoubtedly explain a good deal of private and public behavior. They help account for the fact that poor people seem comparatively uninterested in many forms of environmental protection. There is, however, a third possibility, sometimes realized in the world, in which people's preference for environmental quality is low because of an adaptation to what is available.

If this is so, we should be able to explain both private and public behavior accordingly. Akerlof and Dickens have argued, with some modest evidence, that workers may be unwilling to confront the real magnitude of environmental risks faced in the workplace, because it is too distressing for them to do so. ${ }^{62}$ On this view, workers, having adapted their preferences and beliefs to a relatively risky status quo, attempt to reduce cognitive dissonance by concluding that the dangers are trivial. The claim is speculative and the relevant evidence is largely anecdotal. But there is some empirical support for the general view. Consider the fact that after the Three Mile Island nuclear power plant accident, it was the people who lived on Three Mile Island who, of all those polled, believed that the relevant risks were lowest. ${ }^{63}$

\footnotetext{
${ }^{60}$ Jon Elster, supra note 57.
}

61 Amartya Sen has insisted on this general point in many places. See Amartya Sen, Commodities and Capabilities (1985); Amartya Sen, Inequality Reexamined (1992).

${ }^{62}$ See George Akerlof \& Robert Dickens, The Economic Consequences of Cognitive Dissonance, $72 \mathrm{Am}$. Econ. Rev. 307-18 (1982).

${ }^{63}$ See Elliott Aronson, The Social Animal (4th ed. 1984). It is possible, of course, that the people who lived in this area were better informed. 
If the general claim is right, it would follow that the demand for environmental legislation might be relatively low among people deprived of exposure to environmental quality, and the phenomenon would be attributable to adaptation of preferences to what is available. It is extremely difficult to test this hypothesis against more conventional alternatives stressing learning and rational choice under conditions of deprivation. We might, however, begin to investigate the demand for environmental protection across regions and across nations. It would be especially valuable to see how the demand for environmental quality changes over time, perhaps with exposure to pristine areas, perhaps with a social belief that the degradation of environmental amenities is not inevitable, perhaps with the rise of organizations solving collective action problems of various sorts (see below).

As a normative matter, it might also follow that existing preferences are an uncertain basis for environmental policy, since we cannot without circularity justify environmental outcomes by reference to preferences that those outcomes have generated. Of course there is a risk of totalitarianism here. Of course it is right to insist that government should respect private preferences, partly because of the frustration and resentment that are produced by efforts to bring about change, partly because of the constant risk of ignorance and bias on government's part. But if what I have said here is true, it will be necessary to rethink the underanalyzed and vexing issue of paternalism, in environmental law and elsewhere. ${ }^{64}$

b. Intrapersonal collective action problems.

A closely related problem arises when environmental preferences are a function of past acts of consumption and when such acts alter people's desires or beliefs in such a way as to cause long-term (subjective) harm to them. In such cases, the two key facts are (a) that preferences are endogenous to past consumption decisions and (b) that the effect of those decisions on current preferences is pernicious. The effect is pernicious when the aggregate costs of consumption, over time, exceed the aggregate benefits. The phenomenon is a general one, but it is especially important in the context of environmental protection, where it is often said that it is necessary to alter social or individual habits by inducing people to engage in a different kind of behavior. A pervasive and difficult question involves the cost, especially the transition cost, of the attempted alteration. If preferences are endogenous to past consumption

\footnotetext{
${ }^{64}$ Cf. Amartya Sen, Inequality Reexamined (1992); Hilary Putnam, Renewing Philosophy 183-85 (1992). For a defense of a form of liberal perfectionism-a belief in a principle of autonomy not necessarily tied to existing preferences—see Joseph Raz, The Morality of Freedom (1986).
} 
behavior, we might hypothesize that the cost will often be lower than anticipated, and precisely because of the change in preference that is brought about by new behavior.

Consider the extreme case of an addiction. Here the problem (if there is one ${ }^{65}$ ) is that the costs of not consuming the addictive substance increase dramatically over time, as the benefits of consumption remain constant or fall sharply. ${ }^{66} \mathrm{~A}$ possible result is that the aggregate costs, over time or over a life, of consumption exceed the aggregate benefits, even though the initial consumption choice provides benefits that exceed costs. As a result, people can be made much worse of even by their own lights. In such cases, people, if fully informed, might well not want to become involved with the good in the first place. ${ }^{67}$

This situation might be described as involving an intrapersonal collective action problem, ${ }^{68}$ in which the costs and benefits, within a particular person, of engaging in the same activity change dramatically over time. The key point is that consumption patterns bring about a significant change in preferences and in a way that makes people worse off in the long-run. ${ }^{69}$

While addiction is the most obvious case, ${ }^{70}$ it is part of a broad category, and the broader category includes a wide range of environmental examples. Consider, for example, myopic behavior, defined as a refusal-because the short-

\footnotetext{
${ }^{65}$ It is certainly possible to imagine a case in which people rationally choose to become addicted-that it, they might do so with full information about costs and benefits over time. The subjective benefits may dwarf the subjective costs, even if the benefits diminish and the costs increase. I am suggesting only that this is not always the case. See also note 70 infra.

${ }^{66}$ But see Alan Schwartz, Views of Addiction and the Duty to Warn, 75 Va. L. Rev. 509 (1989); W. Kip Viscusi, Smoking (1992).

${ }^{67}$ Menachem Yaari, Endogenous Changes in Tastes: A Philosophical Discussion, in Decision Theory and Social Ethics: Issues in Social Choice 59 (1978).

${ }^{68}$ Thomas Schelling, Egonomics, or the Art of Self-Management, 68 American Economic Review 290 (Papers and Proceedings) (1978); Jon Elster, Weakness of Will and the Free-Rider Problem, 1 Economics \& Philosophy 231 (1985). See also George Ainslie, Picoeconomics (1992); The Multiple Self (Jon Elster ed. 1989).

${ }^{69}$ Of course all consumption has an effect on preferences. For example, exposure to classical music usually increases appreciation. But the pattern under discussion is a rare one; it is that pattern, producing miserable lives, to which a democracy might respond. To be sure, in practice the response might make things worse rather than better.

${ }^{70}$ There is a growing literature on the issue of rational addiction, a literature with interesting applications for environmental protection. See K.M. Murphy and Gary Becker, A Theory of Rational Addiction, 96 J. Pol. Econ. 675 (1988). I do not believe that there is a substantial difference between the account offered in the text and that offered by Becker and his followers. It does not much matter whether we say that preferences stay constant, and choices change, or that preferences change as a result of choices. (See the discussion supra of the problematic character of the notion of a "preference.") It is possible to say on either account that an addiction is rational; and an intrapersonal collective action can also arise on either account.
} 
term costs exceed the short-term benefits-to engage in activity having long-term benefits that dwarf long-term costs. We can see this at both the social and individual levels. Akrasia, or weakness of the will, has a related structure (though it may also reflect a problem of incommensurability ${ }^{71}$ ). Another kind of intrapersonal collective action problem is produced by habits, in which people engage in behavior because of the subjectively high short-term costs of change, notwithstanding the fact that the long-term benefits exceed the short-term benefits.

Habits that pose intrapersonal collective action problems are a prominent target of environmental regulation. Consider, for example, the issue of compulsory recycling. It may be that the costs of recycling are initially quite high, simply because the change of behavior is unsettling. The costs may include transition costs and the costs produced by private annoyance and irritation. But once people are in the habit of recycling, some of these costs decrease (perhaps because of learning, perhaps because of preference change), and for many people these costs may even turn into benefits. As a possible analogy, consider the habit of brushing one's teeth in the morning. Even for those who dislike brushing most, a failure to brush may be still more costly than brushing, simply because one is in the habit, and because the habit brings about internalized norms.

It may even be that people in the habit of recycling develop certain social norms $^{72}$ that help turn the hedonic costs of environmental protection into hedonic benefits and thus help solve the collective action problems pervasively at stake in environmental regulation. ${ }^{73}$ If so, there is much more to be said on behalf of recycling, as a policy alternative to a disposal tax, than at first appears. ${ }^{74}$ The legally-induced change of preferences may well have salutary long-term consequences, though before proceeding, it is important for government to be certain of this fact.

The same considerations bear on the creation of incentives to use mass transit rather than automobiles. It may be that expenditures on mass transit will be

\footnotetext{
${ }^{71}$ See Martha Nussbaum, Plato on Commensurability and Desire, in Love's Knowledge 106 (1990).

${ }^{72}$ See Gary Becker, The Economic Way of Looking at Life, University of Chicago, Law \& Economics Working Paper No. 12 (1993), at 17: "Economists have too narrow a perspective on commitments. 'Manipulating' the experiences of others to influence their preferences may appear to be inefficient and fraught with uncertainty, but it can be the most effective way available to obtain commitment. Economic theory, especially game theory, needs to incorporate guilt, affection, and related attitudes into preferences in order to have a deeper understanding of when commitments are 'credible."'

${ }^{73}$ Cf. Jon Elster, The Cement of Society (1990).

${ }^{74}$ An excellent argument against compulsory recycling is Peter Mennell, Beyond the Throwaway Society, 17 Ecology L.Q. 655 (1990); but Mennell's treatment does not take adequate account of the endogeneity of preferences.
} 
firmly resisted at first. Indeed, the relevant incentives will have to be very strong in order to encourage people to change their behavior, adaptive as this has been to the cheap automobile transportation. Here is a case in which preferences are highly adaptive to past consumption choices, a fact that helps account for the high premium placed on automobile transportation in the United States as compared to (for example) Germany and Sweden. But once behavior has changed, preferences may change as well, and the subjective costs of using mass transit may well decrease.

This is a speculative hypothesis, and it would be good to test it. Some evidence could be produced from examining experience with compulsory seat belt usage. I hypothesize that after seat belt use has been compelled, the costs of buckling up decrease, and may even turn into benefits, in the sense that an unbuckled belt will produce discomfort and annoyance. It would follow that states that have enacted and then repealed seatbelt laws should see a large shortterm increase in seatbelt use even after a highly publicized repeal.

c. Cascades.

Habits and customs can be vulnerable to large-scale shifts on the basis of relatively mild government interventions. Sometimes the practice of many people is dependent on what other people do. Once some people change their practices, a wide range of others change as well. Thus it has been shown that "mass behavior is often fragile in the sense that small shocks can frequently lead to large shifts in behavior."75

This is so especially in view of the fact that the modest changes sometimes have a large signaling effect for other people. The point has implications for the positive and normative theory of environmental protection. Compulsory behavior-or disclosure of information-may produce a large-scale cascade in a certain direction as a result of new social norms. Something of this kind may have happened with respect to recycling and "green marketing." As a result, the effects of government policy may be quite different from what would be expected if it were assumed that preferences were rigid and fixed. The costs of regulatory change may therefore turn out to be lower than expected.

If this idea is to be used for policy purposes, it would be valuable to come up with precise predictions about the circumstances in which such cascades will occur. But we already have sufficient reason to believe that current tastes and habits are sometimes vulnerable to large-scale shifts.

\footnotetext{
${ }^{75}$ See Sushil Bikhchandani, David Hirshleifer, and Ivo Welch, A Theory of Fads, Fashion, Custom, and Cultural Change as Informational Cascades, 100 J. Polit. Econ. 992 (1992). See also Douglas Baird, Robert Gertner, and Randall Picker, Strategic Behavior and the Law ch. 6 (forthcoming).
} 
d. The availability heuristic.

A final problem is that perceptions of the world are endogenous to what events are psychologically "available," in the sense that they come readily to mind.$^{76}$ This problem should be grouped with the others in this section, for here too, we are dealing with preferences and beliefs that are adaptive to context, and in a way that might have positive implications and also impeach their reliability for policy purposes.

If pervasive, the availability heuristic will produce systematic errors. Assessments of risk will be pervasively biased, in the sense that people will think that some risks (of a nuclear accident, for example) are high, whereas others (of a stroke, for example) are relatively low. One would predict that the availability heuristic would create a kind of crazy-quilt pattern in regulation, with some events calling for stringent regulation and others calling for little or no regulation at all. The regulation would not be closely associated with actual risk levels. This is the pattern we observe. ${ }^{77}$ Studies of American government show extraordinary disparities in expenditures per life saved. ${ }^{78}$

The disparities are plausibly attributed at least in part to the availability heuristic. The dramatic difference between expert and public assessments of risk levels $^{79}$ is very likely an outgrowth of this heuristic, and the difference maps closely onto actual differences in expenditures per life saved. The public demand for regulation therefore appears to be a product of the availability heuristic, which is itself endogenous to the nature and levels of public and private publicity.

Thus, for example, there are enormous expenditures designed to counteract cancers in the workplace, and relatively low expenditures designed to prevent injuries in automobile accidents. The comparative overregulation of certain environmental risks may well be a product of the fact that those risks, when they come to fruition, are highly publicized. Through this route too we might be able to explain the other inexplicably severe controls on nuclear power. We might also be able to explain the extraordinary safety of air travel as compared with other means of transportation. ${ }^{80}$

\footnotetext{
${ }^{76}$ See Noll \& Krier, supra note 8; Kahneman \& Tversky, supra note 7; W. Kip Viscusi, Fatal Tradeoffs (1992).

${ }^{77}$ See appendix B in C. Sunstein, After the Rights Revolution (1990); Stephen Breyer, Breaking the Vicious Circle (1993)..

${ }^{78}$ Id.

${ }^{79}$ See Breyer, supra note 77 .

${ }^{80}$ See Nancy L. Rose, “Fear of Flying? Economic Analyses of Airline Safety,” 6 J. Econ. Persp. 75 (1992).
} 
The availability heuristic also has normative implications. It produces serious biases, and it is important to ensure that these are reduced or eliminated. A comprehensive system of uniform warnings about risk levels ${ }^{81}$ might well make public assessments less dependent on sensationalistic anecdotes, which very much affect the operation of the availability heuristic. Government information policies might bring public and expert judgments more closely into line. If this proves difficult, institutional changes might be introduced so as to introduce the distorting features of the public demand for regulation. ${ }^{82}$

\section{Collective Judgments and Some Unusual Free-Rider Problems}

Environmental measures might reflect the use of law to embody not the preferences that people hold as private consumers, but instead what might be described as collective judgments, which sometimes solve collective action problems with unusual characteristics. In political processes, people's "preferences" - or what backs their choices—are quite different from what they are in market arrangements. They are subject to different norms and different constraints. They are endogenous to the setting in which they appear. It should hardly be surprising that they yield different outcomes. ${ }^{83}$

Consider the fact that some people seek stringent laws protecting the environment or endangered species even though they do not use the public parks or derive material benefits from protection of species-and even though in their private behavior, they are unwilling to do much to protect environmental amenities. The mere existence of certain environmental goods seems to be highly valued by political participants, even if they are not willing to back up the valuation with dollars in private markets. Of course many people are so willing, and many people give to organizations that will do so. But it seems clear that the choices people make as political participants are different from those they make as consumers. It is in part for this reason that democratic outcomes are distinct from those that emerge from markets.

a. The disparity.

The widespread disjunction between political and consumption choices presents something of a puzzle. There are many plausible explanations for the disjunction. It would be possible to suggest that markets reflect individual choice more reliably than politics; that democratic choices differ from market outcomes

\footnotetext{
${ }^{81}$ Cf. Viscusi, supra note 76 .

${ }^{82}$ This is suggested in Breyer, supra note 77.

${ }^{83}$ Cf. the discussion of "dual utility functions" in Howard Margolis, Selfishness, Altruism, and Rationality: A Theory of Social Choice (1982); see also Mark Sagoff, The Economy of the Earth (1987).
} 
largely because of confusion, as voters fail to realize that they must ultimately bear the costs of the programs they favor; that voting patterns reveal a free-rider problem, reflected in a general willingness to support governmental provision of certain goods so long as it is mostly other people who are footing the bill; and that the disparity stems from rational ignorance, as voters, often uninformed about public policy issues, produce political outcomes that are especially unreliable.

Undoubtedly there is something true about each of these claims. Consumer behavior is sometimes a better or more realistic reflection of actual preferences than is political behavior. Moreover, there are distinctive problems in collective behavior-not only because of the foregoing considerations, but also because of the risks of government manipulation of both preferences and choices, and because of the sheer power of collectivities, especially when backed by the force of law. But in light of the fact that preferences-taken either as a motivation for behavior or as behavior itself-depend on context, the very notion of a "better reflection" of "actual" preferences is a confusing one. There is no such thing as an actual (in the sense of unitary or context-free) preference in these settings. Moreover, the difference between market choice and political choice might be explained by the fact that in the environmental arena, political behavior can reflect a variety of influences that are distinct to the context of political deliberation, and that may even justify giving special weight to what emerges through the political setting. These include four possible phenomena.

First, citizens may seek to implement their aspirations in political behavior, but not in private consumption. As citizens, people may seek the aid of the law to bring about a system that they consider to be in some sense higher than what emerges from market ordering. In the environmental arena, this idea may include, for example, protection of the interests of future generations or of nonhuman life.

Second, some people may, in their capacity as political agents, attempt to satisfy altruistic, justice-related, or other-regarding desires. These can diverge from the self-interested preferences sometimes characteristic of markets. ${ }^{84}$ Discussion among political participants may affect the development and expression of preferences. There is a body of empirical work to this effect. ${ }^{85}$ The narrowest explanation is that implicit contracts, arrived at and understood as

\footnotetext{
${ }^{84}$ See Howard Margolis, SelWshness, Altruism, and Rationality: A Theory of Social Choice (1982).

${ }^{85}$ See, e.g., Norman Frohlich \& Joseph Oppenheimer, Choosing Justice (1992).
} 
such through discussion, can help solve collective action problems; but the phenomenon is almost certainly broader than this. ${ }^{86}$

Third, political decisions might vindicate what might be called metapreferences or second-order preferences. People have wishes about their wishes. Sometimes they try to vindicate those second-order wishes, including considered judgments about what is best, through law. Here environmental law may not only protect against collective action problems, but also vindicate second-order judgments about (for example) the importance of aesthetic and recreational values.

Fourth, people may precommit themselves, in democratic processes, to a course of action that they consider to be in the general interest. They may do so in order to protect themselves against what they know to be their own selfishness, myopia, or impulsiveness. The story of Ulysses and the Sirens is the model. The point may well help explain certain aspects of environmental policy, including compulsory recycling statutes ${ }^{87}$

I emphasize that these are only possible accounts of some of what can be observed in the environmental arena. It is undoubtedly true that much of environmental behavior reflects the self-interest of powerful private groups seeking to bring about or to prevent environmental regulation, or to ensure that any such regulation serves their parochial interests. I suggest only that a full explanation of public behavior will have to take account of the phenomena I am describing.

\footnotetext{
${ }^{86}$ Robin Dawes et al., Explaining Discussion-Induced Cooperation, 54 J. of Personality and Social Psych. 811 (1988).

${ }^{87}$ Some qualifications are necessary here. First, these claims might be proved false in any particular case. It might well be that a law justified as reflecting altruistic desires in fact results from the pressures of well-organized private groups, and has nothing to do with altruism at all. This phenomenon is of course a common one. A detailed study of the forces that produce particular legislation, and of divergences between public and private choices, is necessary to evaluate the claims made here. There is thus a rich source for empirical work.

Second, to point to these various possibilities is not at all to deny that market and private behavior frequently reflects considered judgments, altruism, aspirations, or far more complex attitudes toward diverse social goods than is captured in conventional economic accounts about self-interested preferences. There are numerous counterexamples to any such claim. All I mean to suggest is that divergences between market and political behavior will sometimes be attributable to phenomena of this sort.

Third, a democratic system must be built on various safeguards to ensure that its results are in fact a reflection of deliberative processes of the sort described here. Often such processes are distorted by the fact that some groups are more organized than others, by disparities in wealth and influence, and by public and private coercion of various kinds.
} 


\section{b. Explanations.}

Thus far I have suggested that people may seek, through law, to implement collective desires that diverge from market choices. Might we come up with more concrete explanations for the differences? There are a number of possibilities.

First, the collective character of politics, permitting a response to collective action problems, may be relevant. People may not want to implement their considered judgments about environmental protection, or to be altruistic toward future generations, unless there is legal assurance that others will do so as well. More simply, people may prefer not to contribute to a collective benefit if donations are made individually, with no guarantee that others will participate; but their favored system, obtainable only or best through democratic forms, might be one in which they contribute if (but only if) there is assurance that others will do so. Perhaps people feel ashamed if others are contributing and they are not. Perhaps they feel victimized if they are contributing and others are

not. Social norms thus help explain the disparity between public and private behavior.

In any case, and most fundamentally, the satisfaction of environmental aspirations or altruistic goals will sometimes have the characteristics of the more conventional provision of public goods or the solution of prisoners' dilemmas. Both altruism and aspirations have some of the features of a public good. Aspirations are not conventional public goods, because the market does not fail according to ordinary understandings of market failure. But if the most preferred option is to reflect and carry out aspirational or altruistic goals, political action may be the best alternative. Market behavior, even when working well, may fail to do the job.

Second, the collective character of politics might overcome the problem, discussed above, of preferences and beliefs that have adapted, or to some extent adapted, to an environmentally unsatisfactory status quo or to limits in environmental opportunities. Without the possibility of collective action, the status quo may seem intractable, and private behavior and even beliefs will adapt accordingly. But if people can act in concert, preferences might take on a quite different form. Social movements for environmental protection are plausible examples.

Third, social and cultural norms might incline people to express aspirational or altruistic goals more often in political behavior than in markets. Such norms may press people, in their capacity as citizens, in the direction of a concern for others, for justice, or for the public interest.

Fourth, the deliberative aspects of politics, bringing additional information and perspectives to bear, may affect preferences as expressed through 
governmental processes. A principal function of a democratic system is to ensure that through representative processes, new voices, or novel depictions of where interests lie and what they in fact are, can be heard and understood. It should hardly be surprising if preferences, values, and perceptions of environmental welfare are changed as a result of that process.

Fifth, and finally, consumption decisions are a product of the criterion of private willingness to pay. Willingness to pay is a function of ability to pay, and it is only a proxy for utility or welfare ${ }^{88}$ Poor people may be unwilling to pay much for an environmental good, like clean air, that they very much want; rich people may be willing to pay a good deal for things toward which they feel relatively indifferent. Because of the one-person one-vote rule, political behavior helps remove this distortion (which is emphatically not to deny that it introduces many distortions of its own).

\section{c. Qualifications.}

The argument for respecting collective desires seems irresistible if the measure at issue is adopted unanimously. But more serious difficulties are produced if (as is usual) the law imposes on a minority what it regards as a burden rather than a benefit. Suppose, for example, that a majority wants to require recycling, but that a significant minority hates the idea. It might be thought that those who perceive a need to express an aspiration should not be permitted to do so if the consequence is to deprive others of an opportunity to satisfy their preferences.

The foreclosure of the preferences of the minority is unfortunate, but in general it is hard to see what argument there might be for an across-the-board rule against collective action of this sort. If the majority is prohibited from vindicating its considered judgments through legislation, an important democratic arena will be eliminated. The choice is between the considered judgments of the majority and the preferences (and perhaps considered judgments as well) of the minority. On the other hand, the foreclosure of the minority should probably be permitted only when less restrictive alternatives, including private arrangements, are unavailable to serve the same end. In the environmental context, often such alternatives are indeed available.

If what I have said in this section is correct, some environmental measures will result from desires and aspirations that have a distinctive character precisely because they emerge in the political context. It is not right to think that the consumption choice reflects a "true" or "accurate" picture of preferences, and that politics reveals a blunder. Nor is it right to say that the political choice

\footnotetext{
${ }^{88}$ See note supra 10, on intrapersonal comparisons of utility and willingness to pay.
} 
reflects the true picture. The preference and the choice are endogenous to the setting in which they are expressed. There is no unitary "preference" that can be described as accurately reflected individual choice.

I emphasize that I have offered a portrait of what politics might sometimes be, not what it actually, always, or usually is. To know whether the various phenomena are truly at work, it is necessary to investigate the details. But it would be surprising if we could not explain at least some of the disparities between market and political choice on this general ground. At the same time, the disparities provide a reason to value political over market choices, at least under ideal or very favorable conditions.

\section{Diverse Goods, Context, and Commensurability.}

The last point is the most speculative and complex, and its implications for positive and normative work are far from clear. The point starts with the fact that most positive theories assess environmental issues by reference to "preferences" for environmental quality viewed abstractly, through a unitary scale, along the same metric - that of utility or of willingness to pay. This approach is perfectly reasonable in light of the fact that people must make choices under conditions of scarcity, and it therefore seems sensible to say that people behave as if they make things commensurable even if they do not do so knowingly or willingly.

The puzzle stems from the fact that ordinary people appear to resist the use of a unitary scale and the claim of commensurability along a single metric. ${ }^{89} \mathrm{I}$ claim that two goods are incommensurable if they are not valued in the same way and if their assessment along a single metric therefore does violence to our considered judgments about how (not how much) these goods should be valued. This section attempts to see if it is possible to use this fact to make sense out of

\footnotetext{
${ }^{89}$ The philosopher Joseph Raz understands incommensurability in terms of a failure of transitivity: "Two valuable options are incommensurable if (I) neither is better than the other, and (2) there is (or could be) another option which is better than one but is not better than another." Joseph Raz, The Morality of Freedom 325 (1986) (emphasis in original). On this view, A may not be better than B, or vice-versa, but C may be better than A but not better than B.

This statement seems to point to a puzzling or even incomprehensible state of affairs, but Raz shows that it sometimes obtains. I may be indifferent between lunch with a friend and a $\$ 50$ gift. At the same time, I would prefer a $\$ 60$ gift to a $\$ 50$ gift. But I am still indifferent between lunch with a friend and a $\$ 60$ gift. Or: There are two political initiatives that seem to me equally good: Saving two endangered species, or cutting the budget deficit by $\$ 1$ billion. I would prefer a $\$ 1.5$ billion reduction in the budget to a $\$ 1$ billion reduction. But I am indifferent as between a $\$ 1.5$ billion reduction and saving two endangered species. When incommensurability occurs, there is a failure of transitivity. I put to one side two complex questions: (a) whether a failure of transitivity is irrational and (b) whether incommensurability of this sort is frequent. Raz's conception of incommensurability is closely related to that in the text. The failure of transitivity stems from the absence of a single metric from which the three alternatives can be evaluated. Two may be ranked along the same metric, but a third may not.
} 
some otherwise puzzling phenomena relating to the public's environmental judgments. Through this route it may be possible to understand some features of the apparent demand for regulation, and this is so even if we ultimately conclude that the demand is built on confusion or irrationality. Consider a few examples.

a. Some people feel extremely insulted when asked how much they would accept for a specified level of environmental deterioration, treating the question as outrageous or a form of bribery, rather as if they had been asked to sell a child, or a friendship, or a part of their body. "Studies using WTA questions have consistently received a large number of protest answers, such as 'I refuse to sell' or 'I want an extremely large or infinite amount of compensation for agreeing to this,' and have frequently experienced protest rates of 50 percent or more." 90

b. Some people say that environmental goods have infinite value or that the effort to achieve a clean environment should not be "traded off" against other important values. In opinion polls, people sometimes say that we should achieve a clean environmental "regardless of cost."

c. Some apparently popular statutes reflect a kind of environmental absolutism. The Endangered Species Act ${ }^{91}$ forbids balancing except in the rarest of circumstances. Some statutes, including the Delaney Clause, ${ }^{92}$ forbid any entry of carcinogenic substances onto the market, banning tradeoffs of any kind.

d. As noted, there are extraordinary disparities in federal expenditures per life saved. In some environmental programs, risks are prevented at enormous cost; the government is willing to spend relatively little to stop other risks. All current efforts to produce uniformity in expenditures have failed.

Phenomena of these sorts may in the end reflect irrationality, confusion, interest-group power, or sheer chance. But it would be useful to explore whether there might not be some other kind of explanation. When people are thinking in these various ways, exactly what are they doing?

We might hypothesize that people's apparently irrational valuation of environmental goods comes partly from an insistence that diverse social goods should not be assessed according to the same metric. Some people think that these diverse goods should be valued in qualitatively different ways. This is not to deny that people make trade-offs among incommensurable goods. But with

\footnotetext{
${ }^{90}$ E.M. Mitchell and K.S. Carson, Using Surveys to Value Public Goods 34 (1989). “These extreme responses reflect the feelings of outrage often seen when communities are faced with the prospect of accepting a new risk such as a nuclear power plant or waste disposal facility." Daniel Kahneman, Jack Knetch, and Richard Thaler, The Endowment Effect, Loss Aversion, and Status Quo Bias, 5 J. Econ. Persp. 193, 203 (1991).

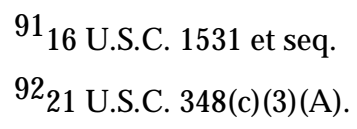


this hypothesis, some apparent anomalies dissolve or become more readily explicable. Some people, for example, rebel against the idea that we should see all of the following, environmentally related consequences as "costs": unemployment, higher prices, greater poverty, dirtier air, more cancer, respiratory problems, the loss of species. It is tempting to say that this is simply an irrational thought. In a way, of course, all of these things are indeed costs; they are harmful things that society should, other things being equal, attempt to reduce. Moreover, the effort to render them commensurable by assimilating them to a unitary category-"costs"-is more than plausible. That effort is motivated by the view that through such assimilation, we will render tractable certain social decisions that otherwise become amorphous and unmanageable. ${ }^{93}$ If we have six, seven, or a thousand desiderata-if we have plural utility functions - and we assume that these are qualitatively distinct, we may not know what to say or do. A choice among them will be rendered too chaotic. Predictions will become impossible.

But it is also possible to understand the resistance to commensurability, captured in the insistence on qualitative distinctions, on diverse modes of valuation, and on the plurality of social goods. The resistance, with roots in John Stuart Mill, ${ }^{94}$ stems from the view that if we make diverse goods commensurable in this way, we will do violence to our considered judgments about how all these should be characterized, experienced, and understood..$^{95}$ Some people think that those considered judgments are not embarrassing, but instead are part of what it means to think well. If all these things are understood as "costs," to be assessed via the same metric, important qualitative distinctions may become lost. Simply as a positive matter, it might be hypothesized when people refuse to trade off environmental quality and other goods, they are making a claim about the diversity of goods and about incommensurability. They are claiming that one set of goods is superior to another not in the sense that it is infinitely valuable, or in the sense that a small amount of it is more valuable than a large amount of

\footnotetext{
${ }^{93}$ For remarks on the origins of this idea, see Martha Nussbaum, Plato on Commensurability and Desire, in Love's Knowledge 106 (1990).

${ }^{94}$ See J.S. Mill, Utilitarianism (1991; originally published 1861), especially the discussion of higher and lower pleasures. A more detailed normative discussion of incommensurability can be found in Cass R. Sunstein, Incommensurability in Law (University of Chicago Law School, unpublished manuscript 1993).

${ }^{95}$ See Amartya Sen, Plural Utility, 80 Proceedings of the Aristotelian Society (1980-81); see also Joseph Raz, The Morality of Freedom (1986); Charles Taylor, The Diversity of Goods, in C. Taylor, Philosophy and the Human Sciences 230, 243 (1985); Anderson, Values, Risks, and Market Norms, 17 Phil. \& Pub. AV. 54, 57-59 (1987); Pildes \& Anderson, Slinging Arrows at Democracy: Social Choice Theory, Value Pluralism, and Democratic Politics, 90 Colum. L. Rev. 2121 (1990); Anderson, Value in Ethics and Economics (forthcoming 1993); Nussbaum, Plato on Commensurability and Desire, in Love's Knowledge (1991).
} 
something else, but in the sense that it is important to see that it is to be valued in a distinctive way and that is therefore stands higher in a hierarchy. ${ }^{96}$

This point leaves many ambiguities, and I will not be able to address them all here. But let us consider, for example, the issue of environmental risks in the workplace. It is clear that people take jobs that expose them to certain risks to health and safety. From this it is tempting to say that a risk of level A is really worth a dollar amount $X$, or that people value their lives at a certain dollar amount. ${ }^{97}$ In a way this makes obvious sense. But suppose that people firmly resist (as is predictable) the conclusion that the view that to them, risk A, or their life, is really worth X. Suppose they claim that this is not in fact their view. To the evidence of their behavior, suppose they respond that they did indeed take the job, but they adamantly resist any broader inference about their tradeoffs between risk and dollars. Is it clear that they are not making sense?

Even if they are indeed not making sense, we might be able to use their responses to understand some otherwise peculiar features of the social demand for environmental regulation. And it is even possible that they are making sense..$^{98}$ If so, it is because their valuation is not an acontextual one or a global judgment about optimization, but instead highly dependent on and geared only to the particular setting in which the choice is made. When a worker accepts a risky job for cash, it may be wrong to say that he "really" thinks that the risk is equivalent to that amount of cash-if the word "really" is intended to capture an abstract, acontextual judgment. Instead he has simply taken the job, and this decision, in its context, may mean nothing more general. Of course it remains possible that the valuation that is expressed through the occupational choice should be the relevant one for those who make policy.

Through this route, it might be possible to help account for phenomena (a) through (d) above. For example, the risk charts might reflect qualitative distinctions among different sorts of hazards. People might not be interested only in cost per life saved, but also in whether the risk was voluntarily assumed; whether the exposed person, the employer, or the employee knows the facts; whether the underlying activity produces valuable goods; whether the hazard is common; whether the exposure is essential to productive activity; whether the

\footnotetext{
${ }^{96}$ See the discussion of hierarchical incommensurability in Pildes \& Anderson, supra note 95. One should not make too much of this claim even if it is descriptively accurate and normatively plausible. It may still be most parsimonious to study behavior as if people believed in commensurability even if they do not, or believe that they do not. Moreover, the fact that people make choices among diverse goods may be all we need to engage the assumption of commensurability.

${ }^{97}$ See W. Kip Viscusi, Risk by Choice (1984); W. Kip Viscusi, Fatal Tradeoffs (1992).

${ }^{98}$ See Pildes \& Anderson, supra note 95; Anderson, supra note 95.
} 
risk is encountered occupationally or elsewhere; whether the people subjected to risk were able to participate in making relevant decisions. ${ }^{99}$ With such questions, it may emerge that people's valuations of different risks will vary a good deal with context. Hence the varying valuations may reflect not irrationality or interest-group pressure, but diverse judgments about qualitatively diverse risks.

I do not claim that the actual disparities can be justified in this way. In view of their obvious irrationality, that conclusion would be extravagant. But it may well be rational to allow widely varying expenditures in light of the diverse factors outlined above, and at least some of the current variations might have some such foundation.

It might also be possible to understand some of the reactions to opinion polls and perhaps environmental legislation as well. Begin with an exotic example. If a pet owner were asked how much he would accept to allow his pet cat or dog to be used for laboratory experiments, he could be insulted and might well respond very much like the people in (a) ${ }^{100}$ This is so even though economic valuation of pets, in terms of purchase price, sale price, and medical expenditures, is perfectly common. This response stems from the fact that the pet owner's ordinary attitude toward his pet is incompatible with the idea that that pet is solely for human experimentation - though that attitude is not incompatible with imposing budgetary limits on sale price and on medical expenditures. In these circumstances the problem is not that the offered price is too low, or that the pet is infinitely valuable, but that the very idea of sale for the purpose of experimentation seems inappropriate. Some people think of freedom from certain environmental risks, and the protection of pristine areas, in just this way. They value the relevant goods not for their use but for their beauty. The emphasis on "use value" inadequately captures the way they value the relevant goods. We might conclude that much of public discussion about the environment is about the appropriate mode (not only the appropriate level) of valuation for diverse human goods.

If something of this kind is right, it may be that people think that the loss through human action of an endangered species is incommensurably (not infinitely) bad, and that this thought should be expressed through regulatory

\footnotetext{
${ }^{99}$ Some of these factors are discussed in William Lowrence, Of Acceptable Risk (1976).

${ }^{100}$ Cf. Anderson, supra note 95 . Note some related puzzles: people do not ask their neighbors to mow their laws, or clean up their house, even for a high price; people do not ask other people to exchange their place in queues for cash; people offer to drive each other home, but they rarely offer to pay for taxis. Some of this is discussed in terms of "social norms" in Jon Elster, The Cement of Society (1989), but I think that an approach that investigates issues of commensurability will be more helpful.
} 
proscriptions. To say the least, this view raises many complexities. All I mean to suggest is that it is a common idea. ${ }^{101}$

In some cases, the claim of incommensurability is understandably but wrongly converted into a claim of infinite value. It is wrongly so converted because people do and must make choices under conditions of scarcity. We might think that (say) a loss of a species cannot really be made commensurable with the loss of jobs, but that neither of these is of infinite value, and that it is appropriate even if tragic to sacrifice one incommensurable good for another. The hard questions, not yet fully elaborated in the philosophical literature, remain: How does one make choices when noncommensurable social goods are at stake, and when some of these must be sacrificed? When noncommensurable goods are at stake, how can choices be assessed as reasonable or not? I cannot attempt to answer these questions here. But attention to valuation of the diverse goods at stake in environmental regulation may well provide relevant information on this subject.

\section{Conclusion}

Recent refinements and qualifications of rational choice theory have important implications for the study of government regulation. Above all, the endogeneity of preferences offers a large area for positive work. Some environmental outcomes can probably be explained by status quo bias and the endowment effect. In particular, these phenomena help account for the asymmetry between old and new risks and the public antipathy toward strategies that create incentives to decrease use of automobiles.

Both private and public behavior in the environmental context are an outgrowth of the fact that environmental preferences are endogenous to available opportunities, to shifting social norms, and to past acts of consumption. Some environmental outcomes may well be a reflection of the asymmetry between political and consumption choices, an asymmetry sometimes attributable to the peculiar features of political deliberation. It is incorrect to say that the consumption choice accurately reflects a preference, whereas a political choice does not. The preference is itself endogenous to the setting in which it is expressed.

Finally, and most tentatively, I suggest that environmental absolutism may sometimes result from a resistance to claims of commensurability between environmental and other goods. From these admittedly speculative claims, there

${ }^{101}$ An especially good discussion can be found in Elizabeth Anderson, supra note 95, chapters 1, 2, and 4. 
is obviously large room for empirical testing, though we do not yet have the tools to find all that is required.

I have made some normative suggestions as well. Private preferences are an inadequate basis for environmental policy insofar as these are adaptive to an environmentally inadequate status quo. At least under ideal conditions (met rarely in the real world), democratic choices about the environment are probably to be preferred over private consumption choices, even if free-rider and informational problems could be solved. Finally, claims of incommensurability among diverse environmental goods are at least plausible so long as they are not confused with claims of infinite valuation. Much remains to be done on this important and difficult subject.

In the end, I believe, these sorts of suggestions will point to the need to question whether private preferences should be the exclusive touchstone of environmental policy. We might venture as well an account of what human beings need for good lives ${ }^{102}$ and try to set up conditions under which democratic decisions about environmental matters can be most fully informed, so as to ensure appropriate valuation of diverse environmental assets. ${ }^{103}$ To undertake such endeavors would be to recover important aspects of the old discipline of political economy But an account of these abstract and complex claims would take me well beyond the present discussion.

${ }^{102}$ This is the direction suggested in Amartya Sen, Inequality Reexamined (1992); Amartya Sen, Commodities and Capabilities (1985).

${ }^{103}$ This is the direction suggested in Elizabeth Anderson, supra note 95. 
This Working Paper is a preliminary version of an article that will be published in The Journal of Legal Studies. Readers with comments should address them to:

\author{
Cass R. Sunstein \\ Karl N. Llewellyn Professor of Jurisprudence \\ The Law School and \\ Department of Political Science \\ The University of Chicago \\ 1111 E. 60th Street \\ Chicago, IL 60637
}




\section{Chicago Working Papers in Law and Economics (Second Series)}

1. William M. Landes, Copyright Protection of Letters, Diaries and Other Unpublished Works: An Economic Approach (July 1991).

2. Richard A. Epstein, The Path to The T. J. Hooper: The Theory and History of Custom in the Law of Tort (August 1991).

3. Cass R. Sunstein, On Property and Constitutionalism (September 1991).

4. Richard A. Posner, Blackmail, Privacy, and Freedom of Contract (February 1992).

5. Randal C. Picker, Security Interests, Misbehavior, and Common Pools (February 1992).

6. Tomas J. Philipson \& Richard A. Posner, Optimal Regulation of AIDS (April 1992).

7. Douglas G. Baird, Revisiting Auctions in Chapter 11 (April 1992).

8. William M. Landes, Sequential versus Unitary Trials: An Economic Analysis (July 1992).

9. William M. Landes \& Richard A. Posner, The Influence of Economics on Law: A Quantitative Study (August 1992).

10. Alan O. Sykes, The Welfare Economics of Immigration Law: A Theoretical Survey With An Analysis of U.S. Policy (September 1992).

11. Douglas G. Baird, 1992 Katz Lecture: Reconstructing Contracts (November 1992).

12. Gary S. Becker, The Economic Way of Looking at Life (January 1993).

13. J. Mark Ramseyer, Credibly Committing to Efficiency Wages: Cotton Spinning Cartels in Imperial Japan (March 1993).

14. Cass R. Sunstein, Endogenous Preferences, Environmental Law (April 1993). 